\title{
Coastal green infrastructure to mitigate coastal squeeze
}

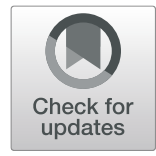

\author{
Valeria Chávez ${ }^{1}$, Debora Lithgow ${ }^{2}$, Miguel Losada ${ }^{3}$ and Rodolfo Silva-Casarin ${ }^{1^{*}}$ (D)
}

\begin{abstract}
Infrastructure is necessary to protect and provide the goods and services required by humans. As coastal green infrastructure (CGI) aims to respect and work with natural processes, it is a feasible response to mitigate or avoid the consequences of coastal squeeze. The concept of CGl is receiving increased attention of late due to the challenges facing us, such as climate change, population growth and the overexploitation of natural resources on the coast. Terms which may be applied to encourage the construction of infrastructure, or to minimize the responsibility for poorly made decisions, often induce misunderstanding. In this paper, the concept of CGI and its use in solving coastal problems is reordered. Four categories are proposed, according to the degree of naturalness of the project: Nature reclamation, Engineered ecosystems, Ecologically enhanced engineering, and Deengineering/Relocation. Existing coastal risk evaluation frameworks can be used to design many types of CGl. Key concepts, challenges and good practices for the holistic management of coastal squeeze are presented from the analysis of successful and unsuccessful CGI projects worldwide.
\end{abstract}

Keywords: Green infrastructure, Solutions based on morphodynamics, Nature-based solutions, Coastal risk mitigation, Coastal infrastructure criteria

\section{Introduction}

Living near any coast has always been challenging, due to occasional events such as storms and floods. Notwithstanding, from earliest times, many communities have settled in coastal zones and have flourished in this everchanging environment. The services provided by the coastal ecosystems [1], and the capacity of humans for adaption to the rich but harsh environment through creative strategies, often outweigh the inherent disadvantages of coastal areas. However, accumulative human activities and increasing urban expansion in coastal zones have often resulted in substantial unforeseen and unintended environmental impacts that threaten human well-being. As far back as 1864, the impact of human actions on nature and humanity were first analysed in "Man and Nature" by George Perkins Marsh [2]. In this comprehensive work, a range of actions are suggested to

\footnotetext{
* Correspondence: rsilvac@iingen.unam.mx

${ }^{1}$ Instituto de Ingeniería, Universidad Nacional Autónoma de México, Edificio

17, Ciudad Universitaria, 04510 Mexico City, Mexico

Full list of author information is available at the end of the article
}

handle various forms of environmental degradation, and the importance of impact awareness is underlined as a means of recovering natural resources that had been lost. Despite criticism of its anthropocentric perspective, this seminal text raised public awareness of how such consequences are ever-present and intertwined. Nature protection policies worldwide were affected by Marsh, and it substantially shaped twentieth century thinking on environmental management [3].

Natural climate cycles of calms and storms, continuous geological processes and environmental particularities all play a part in the evolution of coastal ecosystems [4]. However, such conditions may not be ideal for changing human requirements, leading to remedial actions and the construction of inadequate infrastructure [5].

The unsustainable use of natural resources has increasingly been found to produce consequences which negatively affect the interests of humans. These effects often trigger "coastal squeeze", a term defined and discussed by several authors (e.g. [6-12]), where sea level rise and urbanization (e.g. hard defence structures) have 
been identified as the cause of the reduction of the land/sea space in coastal areas, such as saltmarshes and beaches, inducing a lack of ecosystems ability to migrate and naturally adapt. Silva et al. [13] present a revision of this concept and propose a more comprehensive definition where coastal squeeze is seen as "local, regional, or global anthropic processes, inducing changes with long-term (chronic) negative consequences, which do not allow coastal ecosystems to adapt to global climate change". In contrast to previous works, this definition highlights that land use and human activities near the coast and further away, such as in the upper areas of river basins (agriculture, aquaculture, dams, urbanization), have environmental consequences in different scales of time and space. These processes modify the fluxes of energy and mass, leading to changes in hydrosedimentary and nutrient patterns. In turn, these changes may then induce coastal flooding and erosion, ecosystem loss (including beaches, saltmarshes, seagrass meadows, coral reefs, mangroves, etc.), economic crises and damage to infrastructure, implying considerable cost in terms of protecting the services and the quality of life of coastal communities.

Coastal management based on the morphodynamics of nature must take prevention, mitigation, and adaptation as core tasks. Some of these measures may include embracing local indigenous knowledge that has been previously tried and tested, as well as science-based information that has been recently developed. For example, both drought and flooding are common in coastal areas, and different civilizations have solved these threats in a variety of ways. In the first case, the inhabitants of Pacific atolls build pits, lined with vegetation, to reduce evaporation and create a microhabitat to grow food and medicinal plants [14]. At the other extreme, communities in southwest Bangladesh had, for generations, built temporary embankments to protect their crops from saline intrusion during the dry season, dismantling them during the Monsoons, to allow flooding and fertilization. In the 1960s, several dams were built upriver, increasing crop production but also inducing silting, congesting the drainage system and causing permanent flooding of the crops. The traditional measures were retaken after it was shown that an increased desire for protection can actually add to coastal risk, when system connectivity is not considered [15]. Connectivity refers to the movement of biotic (e.g. plants, animals) and abiotic (e.g. water, sediment, nutrients, etc.) elements that link populations, food webs and ecosystems across coastal and seascapes [16-21]. In recent years, there have been many attempts to write guidelines that incorporate natural processes into the design and implementation of solutions for coastal problems (Fig. 1).

One of the great challenges facing us today is how we use the environment, whether for the exploitation of resources or for the protection of human interests. To assist decision makers whose job it is to ensure the best use of the environment, this paper aims to present strategies, rather than offer generalised prescriptions. Consequently, the manuscript is organised as follows: first, some key concepts that define green infrastructure are presented along with how this can mitigate or avoid coastal squeeze. Then, cases which illustrate the successful implementation of green infrastructure are described, from details published in the specialised literature. Finally, some challenges, examples of good practice, as well as factors that determine green infrastructure success are outlined.

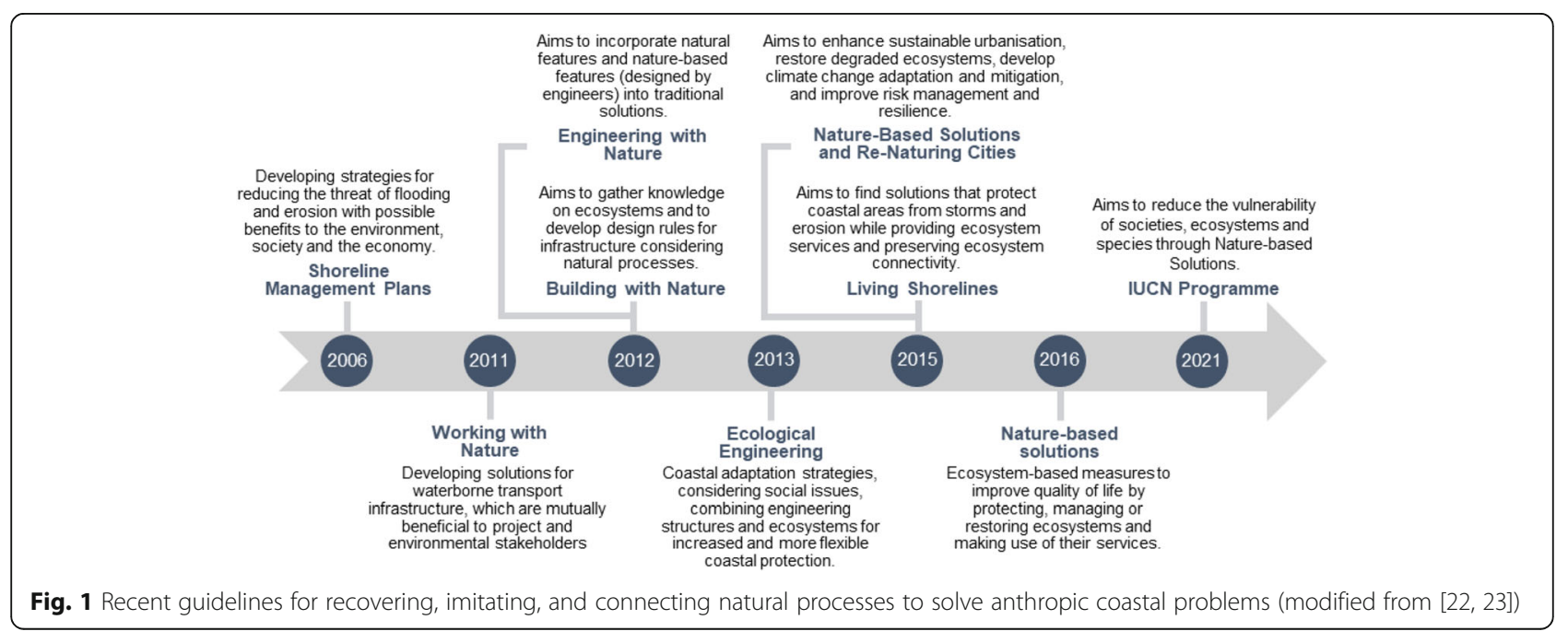




\section{Definition and classification of coastal green infrastructure}

The rise in popularity of green infrastructure in ecological, socioeconomic, and holistic contexts has triggered debates about the need for a common definition. However, after a thorough analysis of the origins, rationales, and semantic content of the different meanings, Seiwert and Rößler [24] found that a single definition is not wide enough. The authors suggest considering green infrastructure as an umbrella term with common basic principles that reflect the diverse needs and contexts in different environments. After all, despite the differences between the definitions, most of them include multiple goals with ecosystem services as cornerstones as Naturebased Solutions, promoted by the IUCN $[23,25]$, to address societal and biodiversity challenges. Most authors who have implemented green infrastructure projects in coastal areas define it as a strategically managed, spatially interconnected network of multifunctional features that deliver ecosystem services [26-32]. For example, Silva et al. [27] recognized that green infrastructure is a series of natural, semi-natural or artificial multifunctional strategies to solve ecological and socioeconomic challenges simultaneously. However, these authors highlighted a) the importance of spatiotemporal connectivity, b) the possibility of successive interventions based on local resources to gradually increase the degree of naturalness without jeopardizing communities' vulnerability and c) benefit from windows of opportunity. These criteria include the explicit recognition of design failures, their correction and the possibility that no infrastructure is needed.

The main attributes of coastal green infrastructure (CGI) are the involvement of multi-scale processes, the recovery or maintenance of the natural connectivity of mass and energy fluxes, and the inclusion of local people in the management of their environment (see Table 1). Therefore, conservation, restoration, and rehabilitation actions are included in CGI schemes. In this context, conservation actions focus on protecting interconnected ecosystems from degradation and increasing their adaptation capacity to global changes [40, 41]. Restoration actions aim to recover the natural trajectories of the ecosystems [42] when the perturbations have not broken their capacity to recover permanently. In turn, rehabilitation actions focus on severely damaged ecosystems where the previous state cannot be recovered, although vital ecosystem services for local human communities can be [43]. Accordingly, green infrastructure aims to avoid the control of ecosystem dynamics that result in their isolation, by using soft and/or hard infrastructure as protective measures (see Table 1).

Table 1 Clarification of concepts used in coastal green infrastructure

\begin{tabular}{|c|c|c|}
\hline Concept & Definition & Notes \\
\hline $\begin{array}{l}\text { Hard infrastructure } \\
\text { or hard engineering } \\
\text { structure }\end{array}$ & $\begin{array}{l}\text { Inflexible/rigid structures constructed both cross and } \\
\text { longshore, for coastal protection (e.g. groins, seawalls and } \\
\text { breakwaters) }[33,34]\end{array}$ & \multirow{2}{*}{$\begin{array}{l}\text { In nature, not all systems work as flexible systems. There are } \\
\text { inflexible "hard" systems (e.g., cliffs, reefs) and others that are } \\
\text { very flexible or "soft" (e.g., sandy beaches, wetlands). } \\
\text { Depending on the benefits of constructing the infrastructure, } \\
\text { it can be categorized as grey or green infrastructure. }\end{array}$} \\
\hline $\begin{array}{l}\text { Soft infrastructure or } \\
\text { soft engineering } \\
\text { structure }\end{array}$ & $\begin{array}{l}\text { Flexible constructions for coastal protection that aims to work } \\
\text { with nature and enhance the habitat: depending on their } \\
\text { intensity, frequency and persistence, drivers (e.g., wind, waves } \\
\text { and runoff) modify the form and position of the structure at } \\
\text { different scales of time and space (e.g. beach nourishments, } \\
\text { artificial dune construction and saltmarsh creation) }[35,36] \text {. }\end{array}$ & \\
\hline Grey infrastructure & $\begin{array}{l}\text { Traditional engineering infrastructure for coastal protection } \\
\text { focused on controlling a physical factor that threatens human } \\
\text { interests (i.e. seawalls and dikes). Also known as structural } \\
\text { measures, ecosystem degradation is usually a consequence of } \\
\text { this type of infrastructure }[37,38] \text {. }\end{array}$ & \multirow[t]{3}{*}{$\begin{array}{l}\text { Both grey and green infrastructure aim to solve a problem } \\
\text { related to human interests. } \\
\text { Grey and green infrastructure concepts are often taken to be } \\
\text { hard/soft solutions. However, green infrastructure is not } \\
\text { necessarily synonymous with soft solutions, nor are rigid } \\
\text { solutions synonymous with grey actions. }\end{array}$} \\
\hline Green infrastructure & $\begin{array}{l}\text { Multifunctional constructions for coastal protection, based on } \\
\text { the conservation of the connectivity of the ecosystem, and the } \\
\text { energy and mass fluxes [27]. }\end{array}$ & \\
\hline Hybrid alternative & $\begin{array}{l}\text { Combines natural and built infrastructure (see [39]). Similarly, } \\
\text { green hybrid projects include infrastructure with different } \\
\text { levels of naturalness. }\end{array}$ & \\
\hline Adaptive solution & $\begin{array}{l}\text { The inclusion of green infrastructure (unique or hybrid } \\
\text { alternative) following a monitoring program; adapting the } \\
\text { solution, based on evidence of its performance, allows } \\
\text { movement from one stage to the next, forward, or backward, } \\
\text { if necessary [22]. This type of solution can be implemented } \\
\text { using a three-step process, as shown in Fig. 2. The range of } \\
\text { possible actions must include the dismantling of the infrastruc- } \\
\text { ture and ensuring economic activities are at a tolerable level } \\
\text { for ecosystem balances. }\end{array}$ & $\begin{array}{l}\text { When we speak of adaptive solutions, we assume that some } \\
\text { degree of flexibility similar to that of a natural system is } \\
\text { mimicked. } \\
\text { This can be naturally self-adaptive in certain conditions, or be } \\
\text { adapted by humans over time. }\end{array}$ \\
\hline
\end{tabular}


Using green infrastructure to satisfy human interests on the coast requires the involvement of several disciplines (physical, ecological, social, economic, etc.), the complexity of which could discourage its use. Figure 3 shows initial steps that would facilitate the initial decision making. Firstly, evaluations are needed to determine whether the resilience of the system has been affected, i.e. if its socio-ecological capacity to recover, learn and adapt after the disturbance had modified the structure and functions of the system [44-49]. The degree of the loss of resilience will determine whether traditional ecological restoration (passive or active) is a feasible alternative for protection. The second step is to identify the availability of biotic elements (e.g., plant propagules needed to recover dune vegetation on nearby dunes or in greenhouses) and abiotic elements (e.g., sediment). The feasibility of recuperating abiotic elements determines whether a green infrastructure plan is viable, or if an alternative, such as traditional infrastructure, is needed until the stressors are controlled. Thirdly, environmental and infrastructure assets must be evaluated, as well as the natural processes that are at risk, as well as what losses exist, and must be paid for. After these steps it will be clearer whether a green infrastructure project is needed, and its technical feasibility. The next stage is to select the most suitable type. Using these criteria, the selection of green infrastructure is then focused on solving a situation that threatens human interests, but includes other objectives, such as the recovery of a range of ecosystem services and ecological connectivity.

Green infrastructure has gained importance in the international arena because it is widely seen as a solution that responds to economic, social and developmental demands while ensuring ecosystem functioning. It is an appropriate tool for balancing the natural functioning of ecosystems and reducing the risks for human interests. Coastal green infrastructure can be classified according to its level of naturalness. Silva et al. [27], propose five types of green infrastructure: Nature-based, Engineered ecosystems, Soft engineering, Ecologically enhanced hard infrastructure, and De-engineering. In this classification, the engineering solutions are grouped as one type, rather than being separated into soft and hard structures, given that traditional engineering includes both types of structures. On the other hand, the first type of this classification (Nature-based) might be confused with the concept of Nature-based Solutions, so it was renamed as Nature reclamation [23, 50]. For these reasons, four types of coastal green infrastructure are proposed, as shown in Table 2.

The decision of which type of green infrastructure can be deployed must involve the evaluation of local characteristics, including the time and space available, and costs (total investment during its useful life), as well as the allowable uncertainties of the response of the coastal environment and the local economy [51]. Table 2 shows that solutions with a greater degree of naturalness, such

Table 2 Types of coastal green infrastructure

\begin{tabular}{|c|c|c|c|}
\hline Types & Definition & Examples & $\begin{array}{l}\text { Local } \\
\text { characteristics } \\
\text { Maximum: } \\
\checkmark \checkmark \checkmark \checkmark \\
\text { Minimum: } \checkmark\end{array}$ \\
\hline $\begin{array}{l}\text { Type } 1 \\
\text { Nature } \\
\text { reclamation }\end{array}$ & $\begin{array}{l}\text { Habitat conservation and restoration are viable and may be } \\
\text { accompanied by other measures to increase ecosystems' ecological } \\
\text { health and resilience. }\end{array}$ & Coastal dune restoration & $\begin{array}{l}\text { Degree of } \\
\text { naturalness: } \\
\checkmark \checkmark \checkmark \checkmark \\
\text { Space: } \checkmark \checkmark \checkmark \checkmark \\
\text { Time: } \checkmark \checkmark \checkmark \checkmark \\
\text { Cost: } \checkmark\end{array}$ \\
\hline $\begin{array}{l}\text { Type } 2 \\
\text { Engineered } \\
\text { ecosystems }\end{array}$ & $\begin{array}{l}\text { Ecosystems are rehabilitated to recover critical services without } \\
\text { reaching the complexity level of natural systems. Natural processes are } \\
\text { allowed to modify ecosystems to a certain degree to return the system } \\
\text { to a more natural form. }\end{array}$ & $\begin{array}{l}\text { Action to allow windows of } \\
\text { opportunities for flora and fauna } \\
\text { recovery }\end{array}$ & $\begin{array}{l}\text { Degree of } \\
\text { naturalness: } \\
\checkmark \checkmark \checkmark \\
\text { Space: } \checkmark \checkmark \checkmark \\
\text { Time: } \checkmark \checkmark \checkmark \\
\text { Cost: } \checkmark \checkmark\end{array}$ \\
\hline $\begin{array}{l}\text { Type } 3 \\
\text { Ecologically } \\
\text { enhanced } \\
\text { engineering }\end{array}$ & $\begin{array}{l}\text { Traditional hard and/or soft engineering measures are modified to } \\
\text { change physical processes, perhaps indirectly producing certain } \\
\text { benefits from the natural processes that are maintained or adapted in } \\
\text { imitation of natural ecosystems. }\end{array}$ & Beach nourishments, artificial coral reefs. & $\begin{array}{l}\text { Degree of } \\
\text { naturalness: } \\
\checkmark \checkmark \\
\text { Space: } \sqrt{ } \checkmark \\
\text { Time: } \sqrt{ } \checkmark \\
\text { Cost: } \sqrt{ } \checkmark \checkmark\end{array}$ \\
\hline $\begin{array}{l}\text { Type } 4 \\
\text { De-engineering/ } \\
\text { Relocation }\end{array}$ & $\begin{array}{l}\text { De-engineering means that hard and/or soft coastal structures are } \\
\text { removed to recover the system and move towards more natural } \\
\text { functioning. These actions are often accompanied by the relocation of } \\
\text { human interests to more convenient sites and conditions. }\end{array}$ & $\begin{array}{l}\text { Removal of coastal defence structures, } \\
\text { retreat of tourist infrastructure (e.g. } \\
\text { restaurants) }\end{array}$ & $\begin{array}{l}\text { Degree of } \\
\text { naturalness: } \checkmark \\
\text { Space: } \sqrt{ } \\
\text { Time: } \checkmark \\
\text { Cost: } \checkmark \sqrt{ } \checkmark \checkmark\end{array}$ \\
\hline
\end{tabular}


as "Nature reclamation" and "Engineered ecosystems", require more time and space, and are associated with more uncertainty. However, those alternatives are usually more affordable in the short-term because local materials are used, and convenient in the long-term because such projects are naturally self-adaptive with fewer maintenance costs associated. In contrast, where the time and space available to act are limited, and uncertainty levels cannot be very high, as in "Ecologically enhanced engineering" and "De-engineering/Relocation" options, the alternatives available have a lower degree of naturalness and a higher economic cost. Of course, some de-engineering and relocation projects are designed to deal with emergency situations in a short time frame and, when the situation and the main stress factors are successfully controlled, complementary solutions with a higher degree of naturalness can be implemented. Perhaps, the conditions for an "Ecosystem engineered" or even a "Nature reclamation" project can be achieved in the medium or long-term.

The selection of the optimal green infrastructure alternative requires an adequate diagnosis for a given site, and this depends on having the necessary information for the analysis. Silva et al. [52, 53], classified the parameters for the diagnosis as ecological, geomorphological, geological, climatic, socioeconomic and legal. The indicators and spatial-temporal domains will depend on local conditions, risk and time available for action. The information is not always complete nor accurate. It may be ideal to have acceptable or the minimum indispensable data. However, these data availability ranges can be considered in choosing an adaptive solution (Fig. 2) that will change in time as information of a better quality becomes available through the monitoring of the project. For example, as Balke et al. proposed [54] to achieve successful vegetation recovery, windows of opportunity (WoO) must be identified. These authors defined WoO as "disturbance-free periods of a critical minimal duration directly following potential diaspore dispersal, which allow seedling establishment and can induce a sudden shift to a new persistent vegetation cover". This concept applies to all green infrastructure types described in Fig. 4, but mainly to natural or soft solutions where drivers, such as energetic waves and wind or extreme events, might compromise the solution success.

For a degraded system, the criteria to include in the selection process are economic, as well as biotic and abiotic elements (e.g. local vegetation and sediment availability). Depending on the urgency or the associated risks, remedial actions can be oriented towards containment of the problem if time, information, and resources are scarce, as shown in Fig. 4. In cases where more time and resources are available, stabilisation measures are possible, and when there is a long-term vision, the level of information is adequate and resources are sufficient and guaranteed, recovery measures are feasible. A hybrid type of green infrastructure may be selected, i.e. a combination of alternatives employed at the same time or in cascade. The term "Neutralise" used in Fig. 4 implies that ecosystem functions can be restored or mimicked to recover the flows of mass and energy that would have existed naturally.

\section{Use of CGI to mitigate coastal squeeze}

The proposed CGI classification included in the CGI decision tree (Fig. 4.) offers a tool to implement green infrastructure projects using the principles proposed in the guidelines for recovering, imitating, and connecting natural processes to solve anthropic coastal problems (Fig. 1). Also, this classification could be helpful to different coastal risk mitigation frameworks, such as the DriverPressure-State-Impact-Response (DPSIR) [55] or the Drivers-Exchanges-State of the environmentConsequences-Responses (DESCR) [13].

In a recent paper analysing the DESCR framework, Silva et al. [13] showed how this framework could be divided in two cycles (DES and CR) and applied to determine the degree of coastal squeeze in a specific area. In
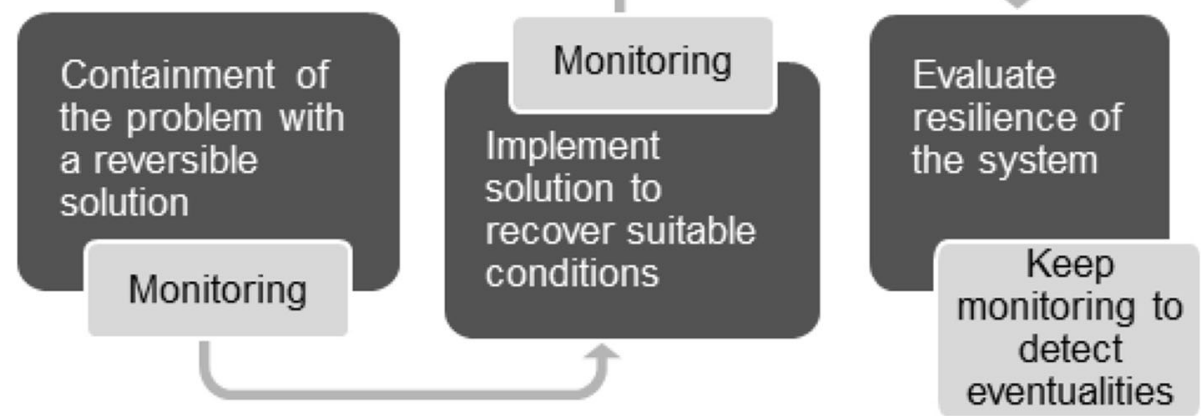

Fig. 2 Three steps in the implementation of adaptive solutions 


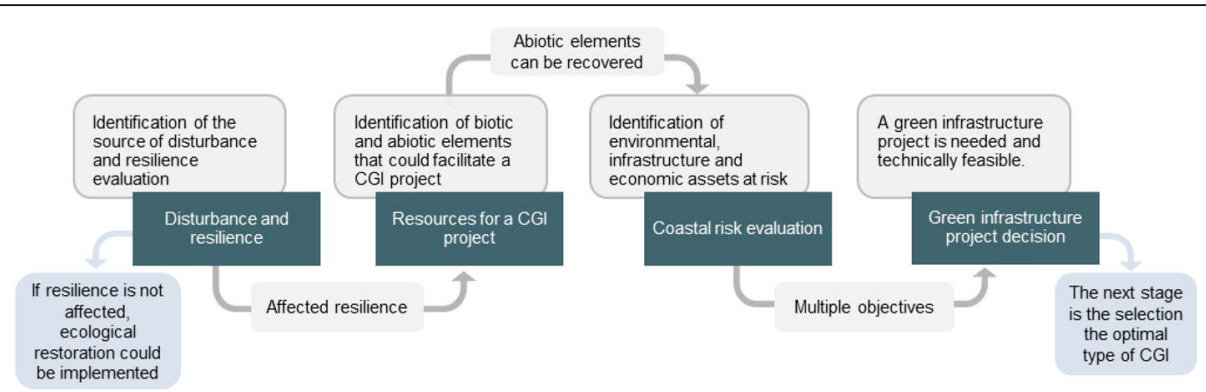

Fig. 3 Evaluating the need for, and feasibility of, a coastal green infrastructure project

this approach, the DES cycle (Driver-Pressure-State) examines the dynamics and the elements affecting the ecosystems of a coastal unit while the $\mathrm{CR}$ cycle (Consequences-Responses) identifies possible actions (Responses) needed to mitigate coastal risks (Consequences). As part of this CR cycle, coastal green infrastructure classification could be a tool to select the "Responses" if the projects focus on recovering ecosystem resilience by controlling stress factors; adapting existing solutions to new scenarios while providing cobenefits and; increasing the capacity of local communities to adapt to coastal squeeze consequences.

Three case studies are presented below, which describe the successful implementation of green solutions. The first example is from Mexico, where an area impacted by unplanned tourism development was readapted to increase the project's sustainability. The second case describes the mimicry of natural sediment transport on a beach in the USA. The last example details a range of green adaptive measures carried out to recover saltmarshes at a site of high ecological and cultural value in the UK.

\section{An engineered ecosystem (type 2 of CGI) at Mayakoba, on the Mexican Caribbean}

The growth of unplanned infrastructure in coastal areas is one of the leading causes of coastal squeeze worldwide and common in the Mexican Caribbean top touristic places [56], where a hotel lessened this phenomenon using green infrastructure [57].

The 200 plus hectare Mayakoba Tourist Development on the Mexican Caribbean contains a range of

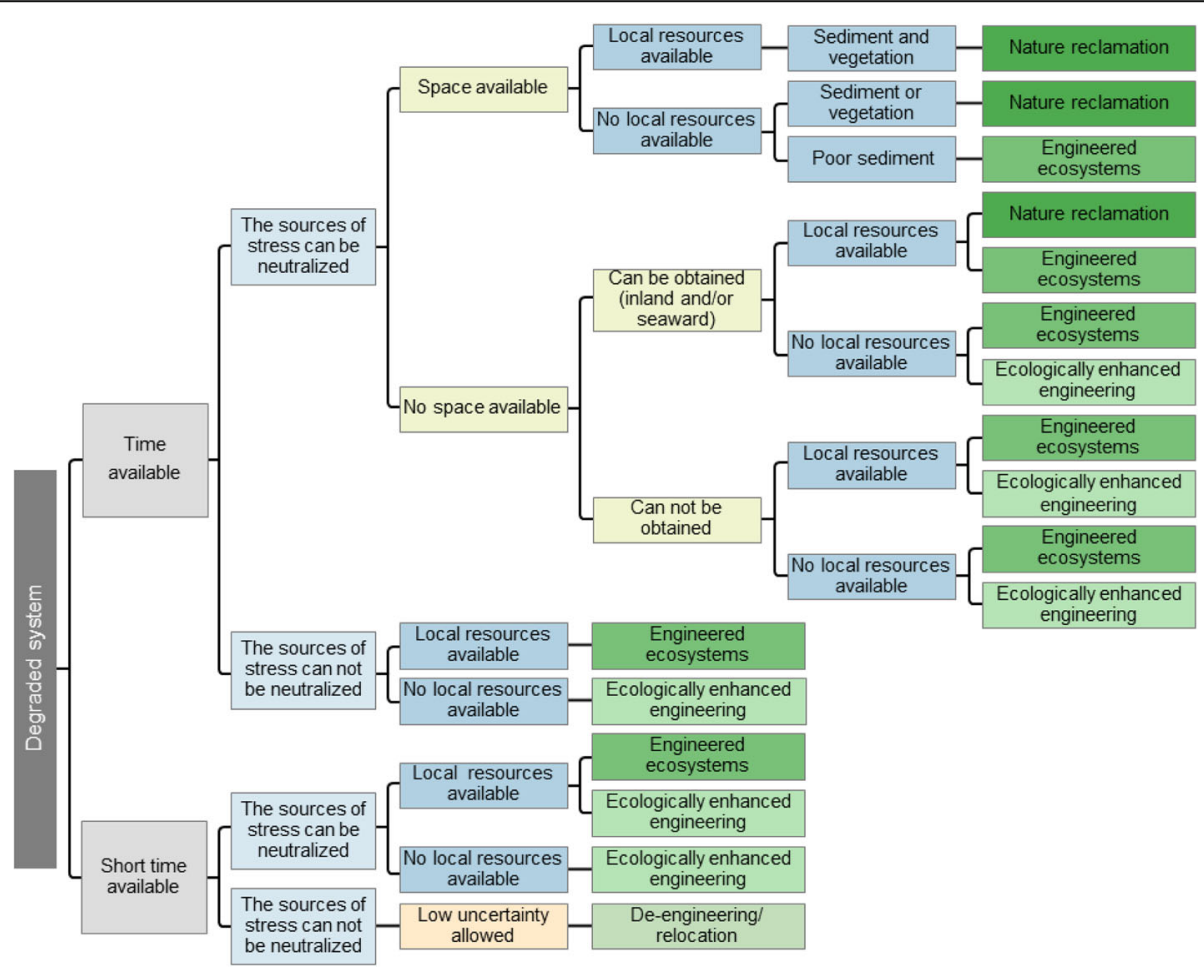

Fig. 4 Single or combined (hybrid) coastal green infrastructure options for a degraded system (modified from [50]) 


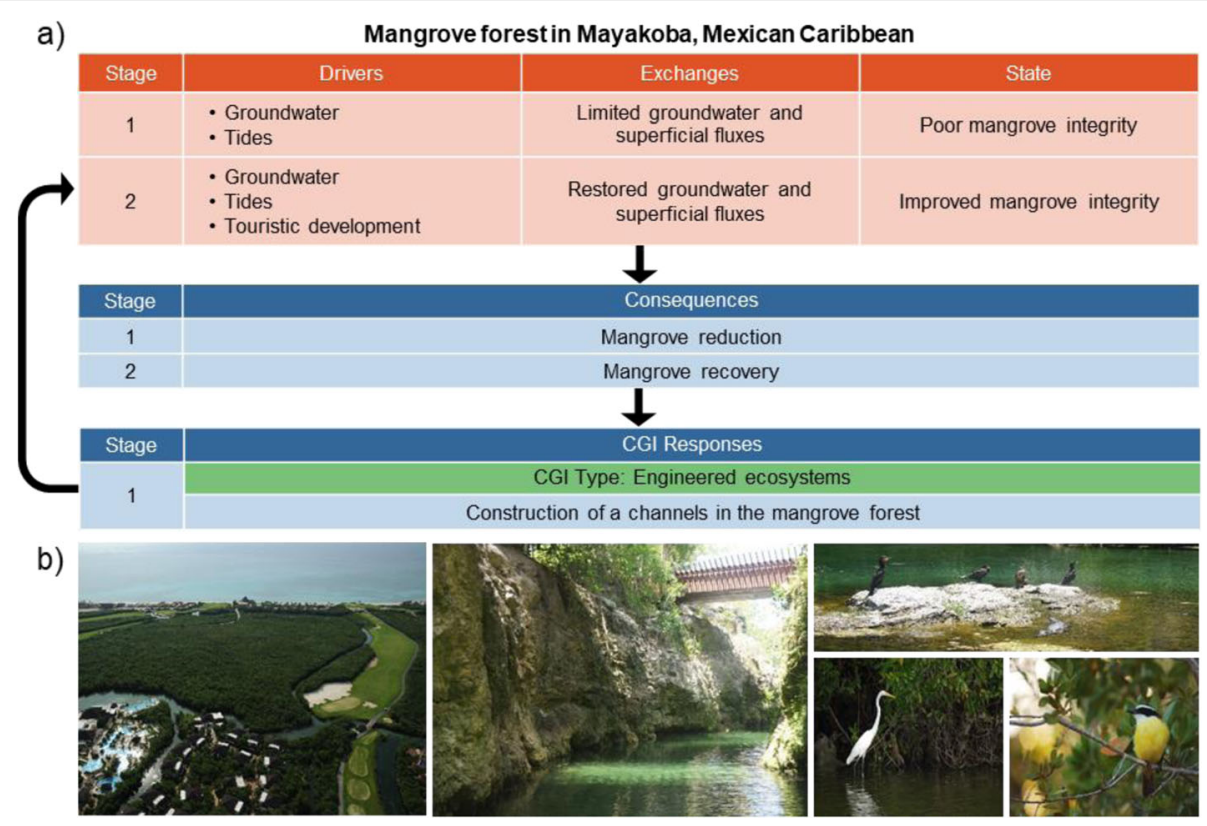

Fig. 5 a Drivers, Exchanges, State of the environment, Consequences and Responses in a mangrove forest on the Mexican Caribbean. b The mangrove wetland was rehabilitated recovering the water fluxes with artificial channels. (Photos by Rodolfo Silva and Mayakoba)

ecosystems: rainforest, mangrove wetland, dunes, beach and coral reefs. Wetlands, in particular, were in poor condition as a result of previous tourist developments that had restricted the surface water and groundwater fluxes. Due to the economic interests associated with tourism development in the area, the recovery of natural flows was not an option. However, the mangrove area was rehabilitated trough an extensive system of channels to recover its ecological value and hedonic ecosystem services, such as providing visitors with the possibility to enjoy aquatic landscapes.
This project is an example of an "Engineered ecosystem" according to the CGI classification (Fig. 4), even though it was begun over 20 years ago. Time was available, the sources of coastal squeeze could be neutralized, the space for the project was obtained, and local resources were accessible, therefore an "Engineered ecosystem" was possible, see Fig. 4. The water fluxes were restored, and the mangrove forest was recovered, thus increasing the ecological and touristic value of the site. Indeed, it has recently been reported that this conserved mangrove area serves as a nesting site for 5 aquatic bird
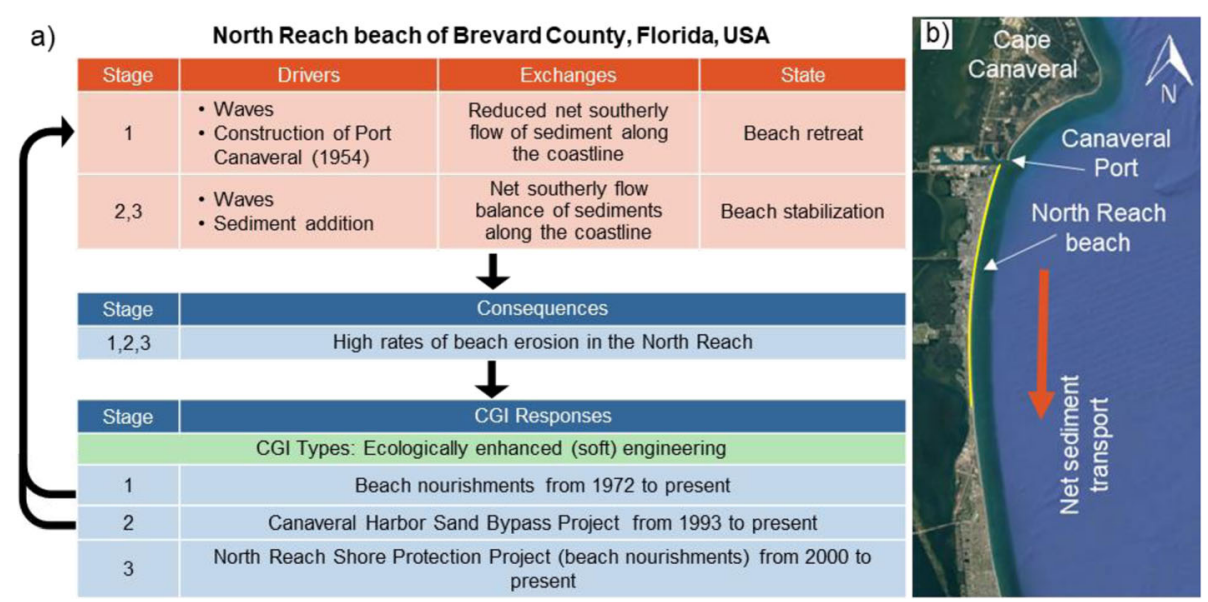

Fig. 6 a Drivers, Exchanges, State of the environment, Consequences and Responses on a beach in the USA. $\mathbf{b}$ Due to chronic erosion, intervention took place on North Reach beach. Image modified from Google Earth 


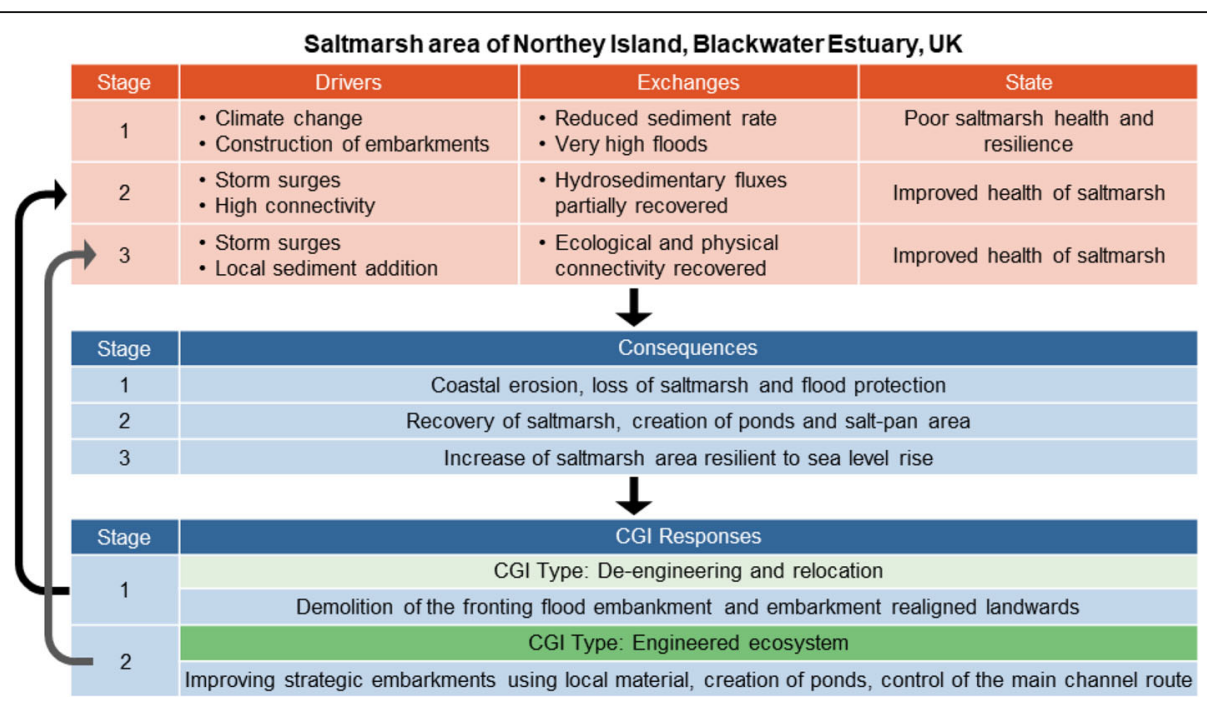

Fig. 7 Drivers, Exchanges, State of the environment, Consequences and Responses in a saltmarsh area in the UK. Intervention took place due to erosion and flooding

species [58]. Figure 5 shows the interaction of elements for this case within the DESCR framework.

\section{A hybrid case: ecologically enhanced engineering (type 3 of CGI) actions in Florida, USA}

North Reach beach, in Brevard County, Florida, has seen a series of management actions to alleviate chronic beach erosion. These beach nourishments and sand bypasses are hybrid schemes of Ecologically enhanced soft engineering [59].

North Reach beach is sheltered to the north by Cape Canaveral and has a net sediment transport from north to south (see Fig. 6). In 1954, the construction of Port Canaveral altered sediment transport patterns in the area, reducing the sediment available for the beach and inducing high rates of beach erosion at North Reach. Beach nourishment projects started in 1972. However, by 1993 the situation had worsened, and so the episodic Canaveral Harbor Sand Bypass Project was implemented, designed to transfer 486,000 cubic metres of sediment from the north to the south of the port every 6 years. Additionally, the North Reach Shore Protection Project began in 2000, authorizing periodic nourishment of the beach for the next 50 years. While $7.8 \times 10^{6} \mathrm{~m}^{3}$ of sediment were placed from 1972 to 2010 [59], leading to a change in the beach state, the chronic erosion prevails. Other adaptive solutions are being implemented as a part of the efforts to mitigate the coastal squeeze in the southern part of the beach.

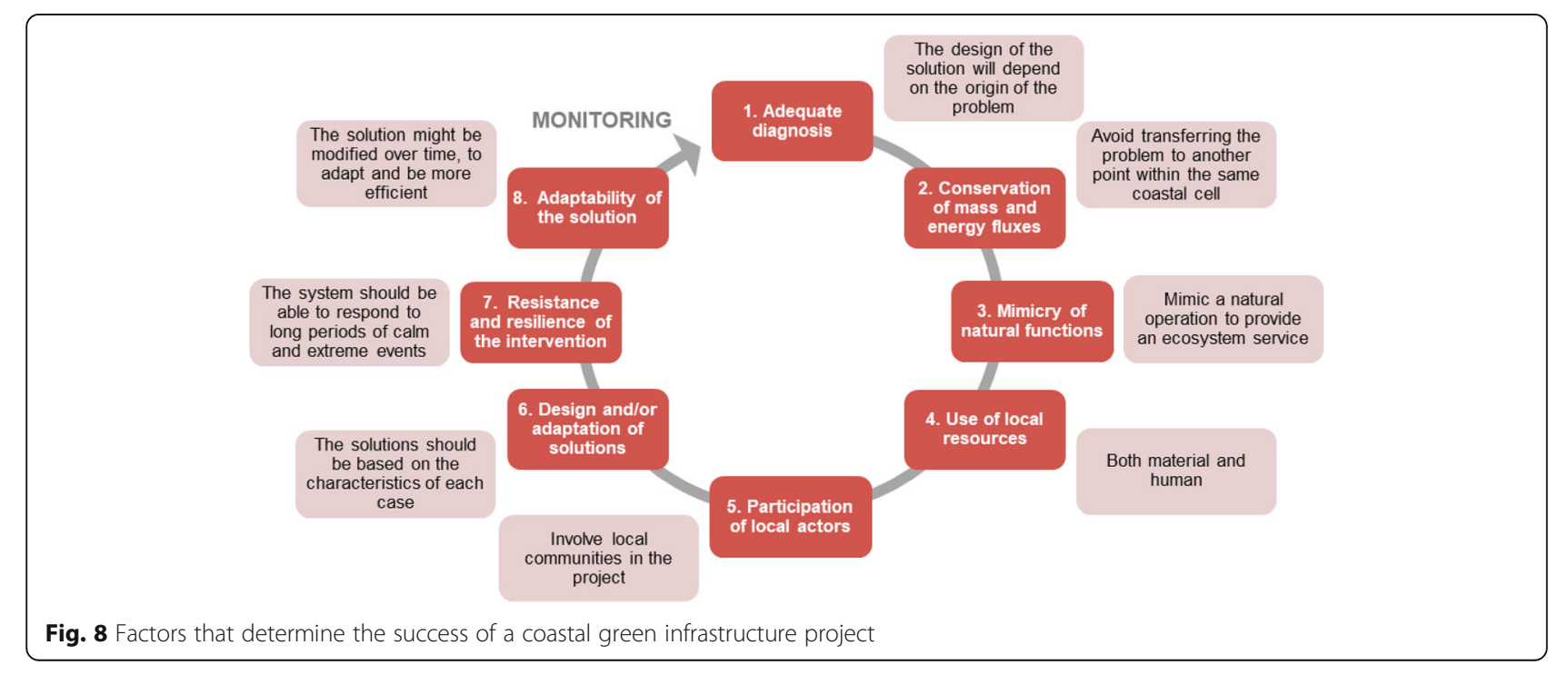




\section{A hybrid case: De-engineering/relocation and an engineered ecosystem (types 2 and 4 of CGI) in the Blackwater estuary, England}

An example of a long-term strategy that includes different types of green infrastructure is seen in the recovery of saltmarshes at Northey Island, in Essex, England [60], an important area from conservation, scientific and heritage standpoints.

Erosive processes associated with the rising sea levels and sea surges in the estuary had repeatedly breached the flood embankments around the island, resulting in their abandonment 100 years ago, and increased the erosion of the saltmarshes on the seaward side of the embankment. In addition, behind the remnants of the embankments, 90 ha of saltmarsh was being affected by the effects of frequent overtopping. In an attempt to open the enclosed land behind the embankments and thus control the consequences of an inevitable failure of the outdated protective structures, in 1991 England's first 'Managed Realignment' took place.

Later, in another phase of this hybrid approach of Coastal Adaptation Strategy, fine estuarine sediment was used to elevate some of the existing saltmarsh, which improved the health of the ecosystem. The establishment of native saltmarsh plant species, previously recorded only in the conservation areas, was subsequently recorded. In addition, the changes in the topography of the saltmarsh have led to a partial recovery of local sedimentary fluxes, which has helped to control the course of the main channels and mitigate coastal squeeze processes.

Even CGI projects classified as "De-engineering/Relocation" must include a phase in which an "Engineered ecosystem" allows modifications of the topography in the short-term to provide the conditions necessary for the long-term relocation of infrastructure. In this case, removing part of the embankment enabled the development of the saltmarsh and the "ecotone" to grassland ecosystem, which has allowed them to adapt to climate change by migrating inland, up-slope, over time (Fig. 7). The path for this type of hybrid alternative can be seen in Fig. 4: there was limited time available, and at first, the sources could not be neutralized. This led to "De-engineering/Relocation". Later, once space was gained and local resources were available, an "Engineered ecosystem" was implemented.

\section{Coastal green infrastructure: deployment challenges and good practice}

Decision-makers need to be able to identify when and where green infrastructure projects can be implemented. This evaluation is only possible if there has been an accurate diagnostic procedure. Since CGI includes elements from several spheres: physical, ecological, social and economic, the successful implementation of a CGI project has many challenges, of which one of the greatest is uncertainty. One of the obstacles that could hinder willingness to invest in these projects is that the factors that increase the chances of success are relatively unknown. These uncertainties are especially relevant when CGI is proposed as an alternative to deal with phenomena such as coastal squeeze, since, by definition, infrastructure and other human interests will be at risk. However, a well-managed green infrastructure project will achieve its objectives and recover costs through the additional ecosystem services it supplies.

Through a literature review, the experience of the authors and a series of interviews with engineers and ecologists who are experts on green infrastructure implementation [53], eight core factors were identified that seem to determine the success or failure of a project (Fig. 8). In all eight of the steps shown in Fig. 8, monitoring is critical. Consequently, the generation of useful information from monitoring, updating of monitoring techniques and access to the results of monitoring is essential. Also, active communication among scientists, decision-makers and policymakers is needed. Local stakeholders should also be engaged throughout the project and contribute to the co-design, co-implementation, and co-monitoring processes.

\section{Conclusions}

From the time the term "green infrastructure" was introduced to the emergence of other terms such as "ecosystem-based solutions", there have been distortions or misunderstandings of these concepts. However, these frameworks are the best we have for dealing with the challenges of protecting long-term human interests. Although the approach of green infrastructure is fundamentally anthropocentric, it is recognised that when humans affect nature negatively, this not only has ethical implications, but also repercussions on human wellbeing. Green infrastructure projects offer the opportunity to mitigate coastal risk by integrating the socioeconomic and political realities of each region while favouring the recovery of the natural functioning of ecosystems.

Sustainable use of the coastal environment depends on understanding the physical-biochemical processes on which the natural balances of coastal ecosystems depend. This understanding can only be achieved with continuous and appropriate long term monitoring. In the long term, green infrastructure needs less investment than traditional infrastructure because it tends to be selfsustaining, and maintenance is usually low-cost. The diagnosis and monitoring of the site are vital for the success of a green infrastructure project. 
Although an ecosystem may have similar symptoms to another (e.g. loss of land or increased flooding), each site has particular conditions due to the local resources and forcing. The implementation of frameworks, such as DESRC, is therefore useful for identifying the different spatial-temporal scales of the problem, and make an appropriate selection from the alternative options. In highly biodiverse regions, there are many opportunities for feasible green infrastructure projects and also many challenges. Challenges include: generating local technical capacities, the search for economic resources, and the establishment of intersectoral communication.

Relatively new concepts considered by different international frameworks have much in common with the green infrastructure concepts presented here, notably considering the importance of ecosystems in long-term solutions. However, great caution is needed, given the ambiguity of terms used in some frameworks. In addition, some of the terms used must be urgently corrected, for example many "natural catastrophes/disasters" should be referred to as catastrophes/disasters of anthropic origin, since this perception takes away blame from the decision makers who wrongly deployed the failed infrastructure.

It is time we recognised that natural ecosystems do not need protection; they should be allowed to function freely without human actions that change the dynamics and balances of the environment. It is vital to encourage the deployment of infrastructure that flows with the natural processes and not the other way around.

\footnotetext{
Abbreviations

CGI: Coastal Green Infrastructure; DPSIR: Driver-Pressure-State-ImpactResponse; DESCR: Drivers-Exchanges-State of the environment-

Consequences-Responses; CR: Consequences and Responses; DES: DriverPressure-State; WoO: Windows of opportunity; USA: United States of America; UK: United Kingdom
}

\section{Acknowledgments}

Not applicable.

\section{Authors' contributions}

RS conceived the idea. VC and DL writing-original draft preparation. RS, VC and $\mathrm{DL}$ writing-review editing. ML review and discussion. The authors read and approved the final manuscript.

\section{Funding}

The authors are grateful to the Inter-American Development Bank (RG-T2675 "Evaluation of the effectiveness of green infrastructure for coastal risk mitigation in LAC") and the CONACYT-SENER-Sustentabilidad Energética project: FSE-2014-06-249795 Centro Mexicano de Innovación en Energía del Océano (CEMIE-Océano) for their financial support.

\section{Availability of data and materials}

All data have been presented in the Position Paper.

\section{Declarations}

\section{Competing interests}

The authors declare that they have no competing interests.

\section{Author details}

'Instituto de Ingeniería, Universidad Nacional Autónoma de México, Edificio 17, Ciudad Universitaria, 04510 Mexico City, Mexico. ${ }^{2}$ Red de Ambiente y Sustentabilidad, Instituto de Ecología, A.C, 91073 Xalapa, Mexico. ${ }^{3}$ Instituto Interuniversitario de Investigación del Sistema Tierra, Universidad de Granada, Avda. del Mediterráneo s/n, 18006 Granada, Spain.

Received: 28 January 2021 Accepted: 27 March 2021

Published online: 09 April 2021

\section{References}

1. Barbier EB, Hacker SD, Kennedy C, Koch EW, Stier AC, Silliman BR (2011) The value of estuarine and coastal ecosystem services. Ecol Monogr 81(2):169193. https://doi.org/10.1890/10-1510.1

2. Marsh GP (1864) Man and nature: or, physical geography as modified by human action, New York. https://doi.org/10.5962/bhl.title.163042

3. Lowenthal D (2000) Nature and morality from George Perkins Marsh to the millennium. J Hist Geogr 26(1):3-23. https://doi.org/10.1006/jhge.1999.0188

4. Cooper JAG, O'Connor MC, Mclvor S (2020) Coastal defences versus coastal ecosystems: a regional appraisal. Mar Policy 111:102332. https://doi.org/10.1 016/j.marpol.2016.02.021

5. Silva R, Martínez ML, Hesp PA, Catalan P, Osorio AF, Martell R, Fossati M, Miot da Silva G, Mariño-Tapia I, Pereira P, Cienguegos R, Klein A, Govaere G (2014) Present and future challenges of coastal erosion in Latin America. J Coast Res 71:1-16. https://doi.org/10.2112/si71-001.1

6. Doody JP (2004) 'Coastal squeeze' - an historical perspective. J Coast Conserv 10(1):129-138. https://doi.org/10.1652/1400-0350(2004)010[0129: CSAHP]2.0.CO;2

7. Schleupner C (2008) Evaluation of coastal squeeze and its consequences for the Caribbean island Martinique. Ocean Coast Manag 51(5):383-390. https:// doi.org/10.1016/j.ocecoaman.2008.01.008

8. Pontee N (2013) Defining coastal squeeze: a discussion. Ocean Coast Manag 84:204-207. https://doi.org/10.1016/j.ocecoaman.2013.07.010

9. Esteves LS (2016) Coastal squeeze. In: Kennish MJ (ed) Encyclopedia of estuaries, 1st edn. Springer, Dordrecht. https://doi.org/10.1007/978-94-0178801-4_405

10. Pontee N (2017) Dispelling the myths surrounding coastal squeeze. In: Flood and Coast 2017 conference. International Centre, Telford 28-30 March 2017

11. Leo KL, Gillies CL, Fitzsimons JA, Hale LZ, Beck MW (2019) Coastal habitat squeeze: a review of adaptation solutions for saltmarsh, mangrove and beach habitats. Ocean Coast Manag 175:180-190. https://doi.org/10.1016/j. ocecoaman.2019.03.019

12. Smart LS, Vukomanovic J, Sills EO, Sanchez G (2021) Cultural ecosystem services caught in a 'coastal squeeze' between sea level rise and urban expansion. Glob Environ Chang 66:102209. https://doi.org/10.1016/j. gloenvcha.2020.102209

13. Silva R, Martínez ML, van Tussenbroek Bl, Guzmán-Rodríguez LO, Mendoza E, López-Portillo J (2020) A framework to manage coastal squeeze. Sustainability 12(24):10610. https://doi.org/10.3390/su122410610

14. Bridges KW, McClatchey WC (2009) Living on the margin: Ethnoecological insights from Marshall islanders at Rongelap atoll. Glob Environ Chang 19(2): 140-146. https://doi.org/10.1016/.gloenvcha.2009.01.009

15. Chowdhooree I (2019) Indigenous knowledge for enhancing community resilience: an experience from the south-western coastal region of Bangladesh. Int J Disaster Risk Reduct 40:101259. https://doi.org/10.1016/j.jdrr.2019.101259

16. Holling CS (1973) Resilience and stability of ecological systems. Annu Rev Ecol Syst 4(1):1-23. https://doi.org/10.1146/annurev.es.04.110173.000245

17. Sheaves M (2009) Consequences of ecological connectivity: the coastal ecosystem mosaic. Mar Ecol Prog Ser 391:107-115. https://doi.org/10.3354/ meps08121

18. Krosby M, Tewksbury J, Haddad NM, Hoekstra J (2010) Ecological connectivity for a changing climate. Conserv Biol 24(6):1686-1689. https:// doi.org/10.1111/j.1523-1739.2010.01585.X

19. Carr MH, Robinson SP, Wahle C, Davis G, Kroll S, Murray S, Schumacker EJ, Williams M (2017) The central importance of ecological spatial connectivity to effective coastal marine protected areas and to meeting the challenges of climate change in the marine environment. Aquat Conserv 27(S1):6-29. https://doi.org/10.1002/aqc.2800

20. Balbar AC, Metaxas A (2019) The current application of ecological connectivity in the design of marine protected areas. Glob Ecol Conserv 17: e00569. https://doi.org/10.1016/j.gecco.2019.e00569 
21. Odériz I, Gómez I, Ventura Y, Díaz V, Escalante A, Gómez DT, Bouma TJ, Silva R (2020) Understanding drivers of connectivity and resilience under tropical cyclones in coastal ecosystems at Puerto Morelos, Mexico. J Coast Res 95(SI): 128-132. https://doi.org/10.2112/si95-025.1

22. Schoonees T, Gijón Mancheño A, Scheres B, Bouma TJ, Silva R, Schlurmann T, Schüttrumpf H (2019) Hard structures for coastal protection, towards greener designs. Estuar Coasts 42(7):1709-1729. https://doi.org/10.1007/ s12237-019-00551-Z

23. IUCN (2020) Nature 2030 one nature, one future - a Programme for the union 2021-2024 DRAFT. Marseille, France

24. Seiwert A, Rößler S (2020) Understanding the term green infrastructure: origins, rationales, semantic content and purposes as well as its relevance for application in spatial planning. Land Use Policy 97:104785. https://doi. org/10.1016/j.landusepol.2020.104785

25. IUCN (2021) Nature-based Solutions. https://www.iucn.org/theme/nature-ba sed-solutions. Accessed on 5 Mar 2021

26. Ruckelshaus MH, Guannel G, Arkema K, Verutes G, Griffin R, Guerry A, Silver J, Faries J, Brenner J, Rosenthal A (2016) Evaluating the benefits of green infrastructure for coastal areas: location, location, location. Coast Manag 44(5):504-516. https://doi.org/10.1080/08920753.2016.1208882

27. Silva R, Lithgow D, Esteves LS, Martínez ML, Moreno-Casasola P, Martell R, Pereira P, Mendoza E, Campos-Cascaredo A, Grez PW, Osorio AF, OsorioCano JD, Rivillas GD (2017) Coastal risk mitigation by green infrastructure in Latin America. Proceed Inst Civil Eng Maritime Eng 170(2):39-54. https://doi. org/10.1680/jmaen.2016.13

28. Nesshöver C, Assmuth T, Irvine KN, Rusch GM, Waylen KA, Delbaere B, Haase D, Jones-Walters L, Keune H, Kovacs E, Krauze K, Külvik M, Rey F, van Dijk J, Vistad Ol, Wilkinson ME, Wittmer H (2017) The science, policy and practice of nature-based solutions: an interdisciplinary perspective. Sci Total Environ 579:1215-1227. https://doi.org/10.1016/j.scitotenv.2016.11.106

29. Morris RL, Konlechner TM, Ghisalberti M, Swearer Stephen E (2018) From grey to green: efficacy of eco-engineering solutions for nature-based coastal defence. Glob Chang Biol 24(5):1827-1842. https://doi.org/1 $0.1111 /$ gcb. 14063

30. Conger T, Chang SE (2019) Developing indicators to identify coastal green infrastructure potential: the case of the Salish Sea region. Ocean Coast Manag 175:53-69. https://doi.org/10.1016/j.ocecoaman.2019.03.011

31. Kumar P, Debele SE, Sahani J, Aragão L, Barisani F, Basu B, Bucchignani E, Charizopoulos N, Di Sabatino S, Domeneghetti A, Edo AS, Finér L, Gallotti G, Juch S, Leo LS, Loupis M, Mickovski SB, Panga D, Pavlova I, Pilla F, Prats AL, Renaud FG, Rutzinger M, Basu AS, Shah MAR, Soini K, Stefanopoulou M, Toth E, Ukonmaanaho L, Vranic S, Zieher T (2020) Towards an operationalisation of nature-based solutions for natural hazards. Sci Total Environ 731:138855. https://doi.org/10.1016/j.scitotenv.2020.138855

32. Caparrós-Martínez JL, Milán-García J, Rueda-López N, de Pablo-Valenciano J (2020) Green infrastructure and water: Ananalysis of global research. Water 12(6):1760. https://doi.org/10.3390/w12061760

33. Rangel-Buitrago N, Williams AT, Anfuso G (2018) Hard protection structures as a principal coastal erosion management strategy along the Caribbean coast of Colombia. A chronicle of pitfalls. Ocean Coast Manag 156:58-75. https://doi.org/10.1016/j.ocecoaman.2017.04.006

34. Karamouz M, Taheri M, Khalili P, Chen X (2019) Building infrastructure resilience in coastal flood risk management. J Water Resour Plan Manag 145(4):04019004. https://doi.org/10.1061/(ASCE)WR.1943-5452.0001043

35. Cooper JAG, McKenna J (2008) Working with natural processes: the challenge for coastal protection strategies. Geogr J 174(4):315-331. https:// doi.org/10.1111/j.1475-4959.2008.00302.x

36. Inácio M, Karnauskaitè D, Mikša K, Gomes E, Kalinauskas M, Pereira P (2020) Nature-based solutions to mitigate coastal floods and associated Socioecological impacts. In: The handbook of environmental chemistry, 1st edn. Springer, Heidelberg

37. Martin D, Bertasi F, Colangelo MA, de Vries M, Frost M, Hawkins SJ, Macpherson E, Moschella PS, Satta MP, Thompson RC, Ceccherelli VU (2005) Ecological impact of coastal defence structures on sediment and mobile fauna: evaluating and forecasting consequences of unavoidable modifications of native habitats. Coast Eng 52(10):1027-1051. https://doi. org/10.1016/j.coastaleng.2005.09.006

38. Reguero BG, Beck MW, Bresch DN, Calil J, Meliane I (2018) Comparing the cost effectiveness of nature-based and coastal adaptation: a case study from the Gulf coast of the United States. PLoS One 13(4):e0192132. https:// doi.org/10.1371/journal.pone.0192132
39. Sutton-Grier AE, Wowk K, Bamford H (2015) Future of our coasts: the potential for natural and hybrid infrastructure to enhance the resilience of our coastal communities, economies and ecosystems. Environ Sci Pol 51: 137-148. https://doi.org/10.1016/j.envsci.2015.04.006

40. Harris LR, Bessinger M, Dayaram A, Holness S, Kirkman S, Livingstone T-C, Lombard AT, Lück-Vogel M, Pfaff M, Sink KJ, Skowno AL, Van Niekerk L (2019) Advancing land-sea integration for ecologically meaningful coastal conservation and management. Biol Conserv 237:81-89. https://doi.org/10.1 016/j.biocon.2019.06.020

41. Fischer J, Riechers M, Loos J, Martin-Lopez B, Temperton VM (2021) Making the UN decade on ecosystem restoration a social-ecological Endeavour. Trends Ecol Evol 36(1):20-28. https://doi.org/10.1016/j.tree.2020.08.018

42. Gann GD, McDonald T, Walder B, Aronson J, Nelson CR, Jonson J, Hallett JG, Eisenberg C, Guariguata MR, Liu J, Hua F, Echeverría C, Gonzales E, Shaw N, Decleer K, Dixon KW (2019) International principles and standards for the practice of ecological restoration. Second edition. Restor Ecol 27(S1):S1-S46. https://doi.org/10.1111/rec.13035

43. Aronson JC, Simberloff D, Ricciardi A, Goodwin N (2018) Restoration science does not need redefinition. Nat Ecol Evol 2(6):916-916. https://doi.org/10.1 038/s41559-018-0536-0

44. Adger WN, Hughes TP, Folke C, Carpenter SR, Rockström J (2005) Socialecological resilience to coastal disasters. Science 309(5737):1036. https://doi. org/10.1126/science.1112122

45. Cumming GS, Peterson GD (2017) Unifying research on social-ecological resilience and collapse. Trends Ecol Evol 32(9):695-713. https://doi.org/10.1 016/j.tree.2017.06.014

46. Martinez ML, Taramelli A, Silva R (2017) Resistance and resilience: facing the multidimensional challenges in coastal areas. J Coast Res 77:1-6. https://doi. org/10.2112/si77-001.1

47. Ferro-Azcona H, Espinoza-Tenorio A, Calderón-Contreras R, Ramenzoni VC, Gómez País MM, Mesa-Jurado MA (2019) Adaptive capacity and socialecological resilience of coastal areas: a systematic review. Ocean Coast Manag 173:36-51. https://doi.org/10.1016/j.ocecoaman.2019.01.005

48. Salomon AK, Quinlan AE, Pang GH, Okamoto DK, Vazquez-Vera L (2019) Measuring social-ecological resilience reveals opportunities for transforming environmental governance. Ecol Soc 24(3):1. https://doi.org/10.2307/26796981

49. Powell EJ, Tyrrell MC, Milliken A, Tirpak JM, Staudinger MD (2019) A review of coastal management approaches to support the integration of ecological and human community planning for climate change. J Coast Conserv 23(1): 1-18. https://doi.org/10.1007/s11852-018-0632-y

50. Directorate-General for Research and Innovation (European Commission) (2015) Towards an EU research and innovation policy agenda for naturebased solutions \& re-naturing cities: Publications Office of the EU. https://op. europa.eu/en/publication-detail/-/publication/fb117980-d5aa-46df-8edc-af3 67cddc202\#. Accessed on 3 Mar 2021

51. Silva R, Oumeraci H, Martínez ML, Chávez V, Lithgow D, van Tussenbroek Bl, van Rijswick HFMW, Bouma TJ (2021) Ten commandments for sustainable, safe, and W/healthy Sandy coasts facing global change. Front Mar Sci 8: 616321. https://doi.org/10.3389/fmars.2021.616321

52. Silva R, Chávez V, Bouma TJ, van Tussenbroek Bl, Arkema KK, Martínez ML, Oumeraci H, Heymans JJ, Osorio AF, Mendoza E, Mancuso M, Asmus M, Pereira P (2019) The incorporation of biophysical and social components in coastal management. Estuar Coasts 42(7):1695-1708. https://doi.org/10.1 007/s12237-019-00559-5

53. Silva Casarín R, Chávez Cerón V, Lithgow Serrano D, Tsuneki H (2020) Evaluación de la efectividad de la infraestructura verde para la mitigación del riesgo costero en América Latina y el Caribe. Publicaciones Banco Interamericano de Desarrollo. https://publications.iadb.org/es/evaluacion-dela-efectividad-de-la-infraestructura-verde-para-la-mitigacion-del-riesgocostero-en. Accessed on 1 Nov 2020

54. Balke T, Herman PMJ, Bouma TJ (2014) Critical transitions in disturbancedriven ecosystems: identifying windows of opportunity for recovery. J Ecol 102(3):700-708. https://doi.org/10.1111/1365-2745.12241

55. Smeets E, Weterings R (1999) Environmental indicators: typology and overview. http://www.geogr.uni-jena.de/fileadmin/Geoinformatik/projekte/ brahmatwinn/Workshops/FEEM/Indicators/EEA_tech_rep_25_Env_Ind.pdf. Accessed on 7 Dec 2020

56. Lithgow D, Martínez ML, Gallego-Fernández JB, Silva R, Ramírez-Vargas DL (2019) Exploring the co-occurrence between coastal squeeze and coastal tourism in a changing climate and its consequences. Tour Manag 74(1):4354. https://doi.org/10.1016/j.tourman.2019.02.005 
57. Zárate-Lomelí D, Rojas-Galaviz J, Sarasola A, Leo C, Day J, Villasuso-Pino M, Padilla-Souza C (2013) The Mayakoba touristic development: a model of sustainable tourism in the Mexican Caribbean. In: Yáñez-Arancibia A, Dávalos-Sotelo R, Day JW (eds) Ecological dimensions for sustainable socio economic development, 1st edn. WIT Transactions on State-of-the-art in Science and Engineering, Southhampton. https://doi.org/10.2495/978-1-84 564-756-8/023

58. Cruz L, Sarmiento C, Velázquez S, Rivas H, Juárez Á, Quiñonez A (2020) Mayakoba Sustentable 2019-2020. https:/view.joomag.com/mayakoba-sustentable-2020revista2020/0429507001564016107?short \&. Accessed on 7 Jan 2020

59. Hearin J (2014) Historical analysis of beach nourishment and its impact on the morphological modal beach state in the north reach of Brevard County, Florida. J Coast Mar Res 2(3):37-53. https://doi.org/10.12966/cmr.10.01.2014

60. Leggett DJ, Dyke P, Cooper N, Brew D (2020) Adapting to coastal change; Northey Island, Essex, UK. In: Hardiman N, Engineers loC (eds) Coastal Management 2019: Joining forces to shape our future coasts, La Rochelle, September 2019. ICE Publishing, London, pp 363-374

\section{Publisher's Note}

Springer Nature remains neutral with regard to jurisdictional claims in published maps and institutional affiliations.

\section{Submit your manuscript to a SpringerOpen ${ }^{\circ}$ journal and benefit from:}

- Convenient online submission

- Rigorous peer review

- Open access: articles freely available online

High visibility within the field

- Retaining the copyright to your article

Submit your next manuscript at $\boldsymbol{\nabla}$ springeropen.com 